ramosa had nematophores on the stem, ani I think so still. sume of his other remarks are so very obvious as to have scarcely required mention, at any rate to biological readers ; a few, how ever, are just such debateable points as I was anxious to have opinions upon from as many naturalists as possible, and $1 \mathrm{am}$ glad to know Prof. Thompson's. I am glad to say a number of biologists have written to me, since the scheme appeared in NATURE, expressing general approval, and criticising various points of detail, and some of them kindly making offers of assist ance in special groups-and without that kind of assistance from specialists I need scarcely say it would be impossibie to carry out the work satisfactorily. The proposal was first brought before the Biological Society of Livernool on November II, and it was only after some weeks of intermittent discussion with some of my friends in that Siocicty (such as Mr. Hanitsch, Mr. Isaac Thompson, and Mr. A. O. Walker) who are suecialists in certain groups of marine invertebrata, ard after correspondence with Canon Norman and other biologists, that I sent the scheme to NATURE, with the view of getting further opinions. Consequently some of the debateable matters alluded to by Prof. Thompson (limits of British area, introduction of certain non-Brit ish forms, specific nomenclature, how to treat records of size and di stribution, best terms to use for zones of depth, and, I may add, for relative abundance) have already been considerably discussed. The other points raised by Prof. Thompson in connection with Antcnnularia only reguire a few words. said $A$. ramosa was "usually branched. Prof. Thompson says it "may sometimes" be unbranched. The difference between these statements is slight. As to dimensions, a zoophyte which grows to 12 , or occasionally to 24 , inches in height, will, of course, be also frequently found of smaller sizes; and it might be the best plan to give the extreme range, say, I to 24 inches. What I gave was the fair average size of most of the specimens dredged or seen in collections, which I still consider to be 6 to 9 inches.

The rest of Prof. Thompson's contention is practically that there are great difficulties in the way of drawing up such a book of the known British marine invertebrate animals, and that if it is ever done it will be more or less incomplete, because Cinon Norman and others (I hope including both Prof. Thompson aud myself) will continue to find new British animals. That is perfectly true-in fact obvious-but the same objection applies more or less to every work on systematic zoology that has ever been published; ; and I do not consider that because our British P'ycnogonids, and some other small groups, are still very imperfectly known, that is any sufficient reason for delaying in definitely an attempt to deal with the rest of the invertebrata. On the contrary my opinion is rather that an approximation is better than nothing, and that every group, or every family, reduced to "IIandbook" form with specific diagnoses and figures must be a distinct gain. I hope P'rof. Thompson will not think that $I$ an trying to dispute all his criticisus, or that $I$ an ungrateful for the trouble he has taken. I have no doubt that he could correct me in many details, and give me great assistance in records, \&c., of zoophytes, pycnogonids, and other groups, and I hope he will do so.

University College, Liverpool, January 20.

PROF. 1)'AkCY ThOMPSUN's letter raises a question which is, I think, well worthy of Prof. Herdman's consideration. 'That a handbook of our marine fauna is needed cannot for a moment be doubted, and the only matter that calls for discussion is one of scope and methol, of ways and means. Prior to the appearance of Prof. Herdman's circular and article I had intended, if possible, to bring this very matter before the British $A$ ssociation at its nex: meeting, belic ving that a scicct Committee of the Association would best be able to further the interests of marine zoology in this respect. But, as the matter now stands, I leave any such action very willingly to Prof. IIerdman's initiative.

Put broadly (although I well know that such a work in Prof. lierdman's hands would by no means have the character of a mere compilation), the question at issue is whether the handbook should be mainly a compilation from existing material, or should express the work of various specialists and be based upon a series of special investigations. For mysclf I agree with P'rof. Thompson, and for the same reasons, that the adoption of the latter alternative would be likely to meet our needs most fully and satisfactorily. It would ensure, as far as possible, the equal treatment of the various groups, and would thus give to

No. 1213 , VOL. 47 ] the book (which is important) a more permanent and authoritative value than could be attained by a book depending upon the personal labours of one zoologist. I feel confident that, should Prof. Herdman admit the force of this consideration and be willing to edit a handbook in which the diagnoses were drawn up for the various groups by specialists or specially-chosen in. vestigators, he would find no difficulty whatever in meeting with willing co-operation.

But I hardly see the point of extending the scope of the work to the extent which Prof. Thompson would seem to desire. We need a handbonk for use around the coasts of our own islands. To include the fauna of the whole North Atlantic would necdlessly add to the size of the work, delay the time of its appearance, and even in the end be incomplete ; while it is doubtful whether the advantages would at all outweigh these defects. W. GARSTANG

Marine Biological Association, Plymouth, January 20.

\section{Fossil Plants as Tests of Climate.}

Mir. J. STARKIE GarnNer, in his interesting review of $\mathrm{Mr}$. Seward's valuable cssay, makes a statement which I fancy may be misinterpreted at page 268 of NATUKE, where he speaks of the fragmentary character of the Arctic tertiary plants, and the inexperience of the collectors. IIe doubtless is referring to the remains of certain supposed "palms and cycarls in the Greenlani? Eocene," but those who have not followed this branch of Arctic research would hardly gather from the review that Prof. Heer has determined a magnincent flora of more than $35^{\circ}$ species from these northern tertiaries, and that he at once pointed out the absence of tropical and subtropical forms, and the fact that large leaves are not only perfectly preserved up to their edges, but that upright trees associated with their fruits and seets prove them to have grown on the spot. "Thus of Sequvia l.angsdorffi," he writes, "we see not only the twigs covered with leaves, but also cones and seeds, and even a male catkin."

In April I875 I endeavoured to give an abstract of all that was then known of Arctic geology, in a series of articles that appearer! in your columns (NATURF, vol. xi. pp. 447, 467, 492, and 508 ), and added some general conclusions of my own, which are lurther accentuated in the joint communications of Colonel Feilden and myself to the Geological Society in 1878 , and in the "Geology Appendix" to Sir George Nares' "Voyage to the Polar Sca," in which expedition Colonel Feilden played a most valuable part. I have ever since carefully followed the progress of Arctic research, and am now of opinion that looking to the identity of a large number of specics (often extending to the varieties of the same) nccurring in the Silurian, Carboniferous, Lias, Oolite, Cretaceous, and Tertiary strata of the Arctic regions, with those occurring in similar strata in Europe and other parts of the world, they point to a common temperature over these areas and probably over the whole world, from Silurian to early (iretaceous times, and that this was the case does not appear to me to be affected by the question as to whether or not these deposits were homotaxeous.

In late Cretaceous times commenced horizontal variation of cold, or what we now term "climate," though previously vertical variation had evidently been present, for the later investigations of Messrs. Blanford appear to place beyond doubt the existence of glaciers in geological times, as was suggested in 1855 by my lamented chief, Sir Andrew Ramsay; but I equally fail to see that the slightest evidence has been anywhere adduced to support the theory of "recurrence of ice-ages," originated by my talented colleague the late Dr. Croll, and now supported with a "modification" by Sir Robert Ball.

The facts, whether we look to the history of plant life, or animal life, or the character of the rocks themselves, appear to me to be all the other way, as they disclose nothing resembling the refrigeration that, gradually increasing in the Tertiary epoch, culminated in the Glacial episode, which choked up the North and Irish Seas with an ice-sheet since man has been an occupant of our islancis.

H. M. Geological Survey, Alderley Edge, Manchester.

Racial Dwarfs in the Pyrenees.

IN consequence of evidence that I had obtained as to the existence of a dwarf race in Spain, I wrote to Mr. McPherson,

" "On the Miocene Flora of North Greenland," by Prof. ()swald Heer. Translated by R. H. Scutt, F. R.S., Brit. Assot, 1357 , pp. 53 . 